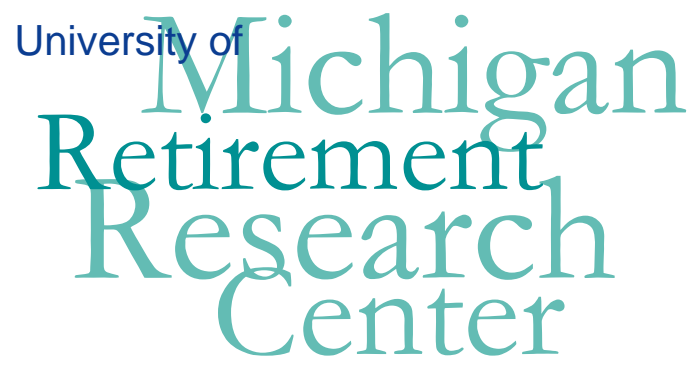

Working Paper

WP 2007-160

\begin{abstract}
Are 401(k) Saving Rates Changing? Cohort/Period Evidence from the Health and Retirement Study

Irena Dushi and Marjorie Honig
\end{abstract}

\begin{tabular}{|l|l|l|l}
\hline $\mathrm{M}$ & $\mathrm{R}$ & Project \#: UM07-05 \\
\hline
\end{tabular} 


\title{
Are 401(k) Saving Rates Changing? Cohort/Period Evidence from the Health and Retirement Study
}

\author{
Irena Dushi \\ Social Security Administration \\ Marjorie Honig \\ Hunter College
}

October 2007

\author{
Michigan Retirement Research Center \\ University of Michigan \\ P.O. Box 1248 \\ Ann Arbor, MI 48104 \\ http://www.mrrc.isr.umich.edu/
}

(734) 615-0422

\section{Acknowledgements}

This work was supported by a grant from the Social Security Administration through the Michigan Retirement Research Center (Grant \# 10-P-98362-5-04). The findings and conclusions expressed are solely those of the author and do not represent the views of the Social Security Administration, any agency of the Federal government, or the Michigan Retirement Research Center.

\section{Regents of the University of Michigan}

Julia Donovan Darrow, Ann Arbor; Laurence B. Deitch, Bingham Farms; Olivia P. Maynard, Goodrich; Rebecca McGowan, Ann Arbor; Andrea Fischer Newman, Ann Arbor; Andrew C. Richner, Grosse Pointe Park; S. Martin Taylor, Gross Pointe Farms; Katherine E. White, Ann Arbor; Mary Sue Coleman, ex officio 


\title{
Are 401(k) Saving Rates Changing? Cohort/Period Evidence
}

\author{
Irena Dushi and Marjorie Honig
}

\begin{abstract}
This research examines the determinants of eligibility and participation in 401(k) plans using two cross-sections of data from the Health and Retirement Study. Our sample consists of workers ages 51-56 representing two cohorts: the original HRS cohort born 1931-41, first interviewed in 1992, and the Early Baby Boomer (EBB) cohort born 194853, interviewed in 2004. Participation in 401(k) pensions in the EBB cohort is nearly 50 percent greater than that of the earlier cohort. This substantial growth in 401(k) plan participation over a relatively brief period may reflect intrinsic differences in tastes between the two cohorts, changes over this period in the external environment regarding retirement saving, or the joint effects of both influences.
\end{abstract}

\section{Authors' Acknowledgements}

The research reported herein was supported by a grant from the Social Security Administration through the Michigan Retirement Research Center (UM07-05). The findings and conclusions expressed here are solely those of the authors and do not represent the views of the Social Security Administration, any agency of the Federal government, or the Michigan Retirement Research Center. The authors thank Alan Gustman for helpful comments and discussion. 


\section{Are 401(k) Saving Rates Changing? Cohort/Period Evidence from the Health and Retirement Study}

Defined contribution pensions have become the predominant form of retirement saving among U.S. workers. By 2003, more than 60 percent of workers with pensions depended exclusively on a defined contribution plan, and an additional 30 percent had dual coverage under both defined contribution and defined benefit plans (Buessing and Soto 2006). The replacement of defined benefit by defined contribution pensions has shifted the responsibility for providing adequate savings for retirement to the individual employee through decisions made over the working life: whether to participate if offered and eligible for an employer's plan, how much to contribute each year, conditional on participation, and whether to draw down accumulated savings prior to retirement. Decisions resulting in significant saving shortfalls at retirement compromise retirees' overall well being and are a matter of public, as well as private, concern. Thus it is important to assess the factors determining pre-retirement saving and to understand the saving patterns that have been evolving during this period of change from defined benefit to defined contribution plans. We examine the determinants of eligibility, participation, and the rate of saving conditional on participation in the most common form of defined contribution pensions, 401(k) plans.

Previous research on participation and saving in defined contribution plans has used either household survey data that lack information on plan characteristics (Current Population 
Survey, Survey of Consumer Finances, or the Survey of Income and Program Participation), or employer surveys that provide plan details but lack household information (Andrews 1992, Papke 1995, Papke and Poterba 1995, Bernheim and Garrett 1996, Clark and Schieber 1998, Bassett, Fleming, and Rodrigues 1998, Munnell, Sunden, and Taylor 2001, and Smith, Johnson and Muller 2004). Exceptions are Papke (2003), who uses the self-reported demographic and pension data in the 1992 wave of the Health and Retirement Study, and Cunningham and Engelhardt (2002), who match self-reported information on respondents in the 1992 wave of the Health and Retirement Study with data on tax-deferred contributions from restricted Social Security Administration earnings records and information on plan characteristics from employerprovided summary plan descriptions.

Findings in these studies indicate that the probability of participation in 401(k) plans increases with age, education, household income, job tenure, and whether the employer matches employee contributions. Conditional on participation, contributions are found to increase with age, job tenure, household income, defined benefit pension wealth, private net worth, and the planning horizon; findings on the impact of an employer match are mixed. Alternative pension coverage is found to reduce 401(k) saving, whereas employee direction of investment funds is associated with higher saving rates. A number of researchers have noted that their findings may not apply to younger cohorts.

This study is the first to compare 401(k) plan participation and contributions between pre- and post-World War II cohorts. We use data from the Health and Retirement Study (HRS), a longitudinal nationally representative survey of individuals ages 51 and older and their spouses of any age, first interviewed in 1992 and biennially thereafter, with additional cohorts added in 
1998 and 2004. ${ }^{1}$ The HRS also includes information from respondents' employers regarding pension plans available to employees, as well as respondents' administrative earnings histories from the Social Security Administration. ${ }^{2}$ We examine the participation and contribution decisions of two cohorts at the same ages (51-56): the original HRS cohort (born 1931-41 and interviewed in 1992) and the younger Early Baby Boomer (EBB) cohort (born 1948-53), which was added to the survey in 2004.

We find that eligibility for 401(k) plans increased 40 percent between 1992 and 2004, from a rate of .42 in the HRS cohort to .59 in the EBB cohort. Despite the expansion of the eligibility base, participation in the EBB cohort conditional on eligibility is marginally higher, .70, compared to .66 in the earlier cohort. Overall participation is thus substantially higher among members of the EBB cohort. Participation in this cohort, conditional on eligibility, is associated with higher earnings, a white collar occupation, having a defined benefit pension in the current job, tenure longer than five years, and an employer match of contributions. In addition, participation is higher among married employees whose spouses have, or had a defined contribution pension in either a current or previous job.

\section{401(k) Pensions}

A form of defined contribution pension, 401(k) plans are employment-based pensions that allow employees to make elective contributions on a pre-tax basis through salary reduction. The term "401(k)" refers to defined contribution plans qualified under section 401(k) of the Internal Revenue Code. The term is used more broadly, however, to refer to a number of plans with similar features. Savings or thrift plans that allow pre-tax contributions from salary

\footnotetext{
${ }^{1}$ Detailed descriptions of the data are in Moon and Juster (1995), Smith (1995), and Gustman and Steinmeier (1999b, 1999c).

${ }^{2}$ Employer and Social Security data are available to researchers on a restricted bases only.
} 
reduction are included in this category, as are profit-sharing plans. Qualified nonprofit organizations and public school systems may offer such plans, provided for in section 403(b) of the Internal Revenue Code (IRC). Plans for state and local government employees qualified under section 457 of the IRC also have 401(k)-type features. ${ }^{3}$

A distinguishing feature of these plans is that they allow for contributions from employers, who may match a pre-determined fraction of the employee's contribution. A typical match is 50 percent of employee contributions up to 6 percent of wages and salary. Funds in the employee's account, both contributions and investment earnings, are not taxed during the accrual period but are taxed as ordinary income on withdrawal.

\section{Data}

We use data from the Health and Retirement Study, a longitudinal survey of a sample of individuals ages 51 and older who were first interviewed in 1992 (referred to here as the HRS cohort) and biennially thereafter, with additional cohorts added in 1998 (War Babies cohort) and 2004 (the EBB cohort). Our samples consist of private sector wage-earners ages 51-56 in the HRS and EBB cohorts who reported that they were either included in some type of pension (defined contribution, defined benefit, or both) or who knew whether their employers offered any such pensions. We define respondents as eligible for a 401(k) pension if they reported either that they were included in a 401(k) plan or that they had been offered such a plan and were eligible. Eligible respondents are defined as participating if they reported having made a positive contribution to a plan during the survey year. ${ }^{4}$

\footnotetext{
${ }^{3} \mathrm{~A}$ more detailed discussion appears in Engelhardt (2001).

${ }^{4}$ This definition follows Poterba, Venti, and Wise (1994) and Engelhardt (2001).
} 
The HRS and EBB cohorts were interviewed 12 years apart (1992 and 2004), a period in which the U.S. pension environment changed in important ways. To reflect these developments, the kinds of questions asked in the Health and Retirement Study and the amount of detail solicited from respondents about pensions also changed. These differences present some challenges to the researcher when comparing the saving behavior of members of the two cohorts.

Respondents in the HRS cohort, for example, were asked detailed questions concerning the pensions in which they were included in their current job, but relatively little about the pensions they were offered but chose not to participate in. They were initially asked the following question:

"Now I'd like to ask about pension or retirement plans on your job, sponsored by your employer or union. This includes not only basic pension or retirement plans, but also taxdeferred plans like thrift, savings, 401k, deferred profit-sharing, or stock ownership plans. Are you included in any such pension, retirement, or tax-deferred plan with this employer?”

If the respondent answered "yes," detailed questions were then asked about each plan to a maximum of three plans. These questions included the type of plan, e.g., formula-based (DB), account-based (DC), or a combination of the two. Respondents reporting a DC plan were then asked to identify the type of plan from a choice of the following possibilities: thrift or savings; 401(k)/403(b)/Salary Reduction Agreement (SRA); profit-sharing; stock purchase/employee stock option; and other. We define thrift or savings plans, 401(k)/403(b)/SRA, and a combination of 401(k)/403(b)/SRA and thrift or savings plans as 401(k) plans. ${ }^{5}$ Respondents reporting that they were not included in a pension or retirement plan were then asked whether their employer offered "any such plans" (those listed in the question cited above), and if so, whether they were eligible "to be included in any of these plans." Respondents reporting that

\footnotetext{
${ }^{5}$ We follow definitions used in Poterba, Venti, and Wise $(1994,1995)$ and Engelhardt $(2001)$. We refer to all 401(k)-type plans as 401(k) plans.
} 
they were both offered and eligible were not, however, asked to identify the specific type of plan for which they were eligible.

Respondents in the EBB cohort interviewed in 2004 were asked identical questions regarding whether they were included in a plan/s offered by an employer or union and, if not included, whether they were offered and eligible for any such plans. If they responded that they were offered and eligible, they were asked the following:

"What kind of plans are these? (In some retirement plans, call them Type A, benefits are usually based on a formula involving age, years of service and salary. In other plans, call them Type B, money is accumulated in an account for you.) Are these plans of Type A, Type B, or both?”

If respondents said they were eligible for Type B (account plan), or both Type B and Type A, they were asked the following question:

"Could you tell me a little more about the account plan(s) offered by your employer?

Do they include a thrift or savings plan, a 401K, a 403B, a Supplemental Retirement Account, a profit-sharing plan, a stock purchase plan, a money purchase plan, cash balance, or what?”

To compensate for the omission in the HRS of a similar question regarding plan type for respondents not included in but offered and eligible for "any such plans,” we assume that all such respondents are eligible for a 401(k) plan. We base our decision on two sources of information: independent survey data gathered within three years of the HRS interview, and a pattern in the more recent EBB cohort that corroborates the survey data. Tabulations from the 1995 Survey of Consumer Finances indicate that more than 80 percent of individuals who reported they were not included in, but were eligible for, a pension were eligible for a 401(k). ${ }^{6}$ Among 392 respondents in our sample of the EBB cohort who reported that they were not

\footnotetext{
${ }^{6}$ These data are the basis for adoption of this assumption in Pence (1999) and Engelhardt (2001). We exclude respondents who reported that they were offered a plan but not eligible, as well as those who did not know their eligibility status. While eligibility for 401(k) plans normally begins within a short time after the start of employment, many firms do not grant eligibility to part-time employees.
} 
included in, but were offered and eligible for a pension, 92\% (359) reported that it was an account type plan. Of those, 334 said it was a 401(k) plan and 14 reported a 403(b) plan. In addition, respondents in the EBB cohort who reported being included only in a defined benefit (DB) pension were asked a follow-up question regarding whether their employers offered a 401(k) plan, information not elicited from HRS respondents. To provide comparable information for the earlier cohort on offers of DC plans, we match the records of HRS cohort respondents self-reporting coverage by a DB pension only with employer records indicating the number and type of plans offered. As a result of this matching process, we are able to retain in our HRS sample a total of 595 of the 945 respondents who reported having a DB pension only. ${ }^{7}$ Of these, according to their employers, 198 were offered both a DB and a DC pension. We assume that these DC pensions were 401(k) plans and that the employees were eligible. ${ }^{8}$

\section{Estimation Results}

Table 1 presents probit estimates of employee eligibility and participation in 401(k) plans in the HRS and EBB cohorts. Columns (1) and (5) present the marginal effects of demographic and employment-related characteristics on eligibility for a 401(k) plan, and columns (3) and (7) present the marginal effects of these and additional indicators associated with participation in a plan. The entry in each column reflects the marginal change in the dependent variable for a discrete change in the associated indicator from 0 to 1.

\footnotetext{
${ }^{7}$ Employer records are not available for all respondents.

${ }^{8}$ Because our analysis focuses on self-reported data, we do not use employer data to correct misreporting of pension type by respondents. An analysis comparing self reports with both employer and W-2 form data is currently in progress.
} 
We first examine differences between the two cohorts in the determinants of employee eligibility for 401(k) plans. ${ }^{9}$ Among members of the HRS cohort (col. 1), college graduates are more likely to be eligible to participate in 401(k) plans than are those with a high school education. ${ }^{10}$ By occupational status, however, white-collar workers and managers are no more likely than blue-collar workers to be eligible. By industry classification, moreover, employees in the finance, insurance, and real estate industries are more likely to be eligible than those in manufacturing (the omitted category); the latter, however, are more likely to be eligible than those in professional and related services.

Members of this cohort working full-time, employed in firms with more than 100 employees, and with job tenure of more than five years are more likely to be eligible for 401(k) plans. ${ }^{11}$ Employees with annual earnings in the upper quintiles of the earnings distribution are more likely to be offered and eligible for this type of pension than those in the lowest quintile. Since by law, firms are not allowed to discriminate among employees at different salary levels in the offer of DC pensions, this result suggests that higher wage firms are more likely to offer 401(k) plans. Finally, neither gender, nor race and ethnicity are associated with eligibility among members of this cohort.

Eligible employees in the more recent EBB cohort (col. 5) reflect the significant expansion of 401(k) pensions throughout the labor force. Employees with a high school education are as likely as college graduates to be offered and eligible for 401(k) plans, and employees in manufacturing are marginally more likely to be eligible than those in the finance,

\footnotetext{
${ }^{9}$ Appendix Table 1 presents sample means. Eligibility requirements in firms offering 401(k) plans are generally limited to a minimal length of service and, in some firms, to full-time status. We therefore do not estimate eligibility conditional on offer, but instead include tenure and full-time status as determinants of eligibility estimated on the sample of private sector wage-earners.

${ }^{10}$ In the omitted category, 19 percent of the HRS cohort and 9.7 percent of the EBB cohort did not graduate from high school.

${ }^{11}$ Given the narrow age range of our samples, tenure effects are likely to reflect time on the job rather than age differences.
} 
real estate, and insurance industries. Similar to the earlier cohort, however, employees in large firms, full-time workers, and those with tenure of more than five years are more likely to be eligible, as well as those whose annual earnings are in the four upper quintiles of the earnings distribution. In neither cohort, moreover, does having a defined benefit pension in the current job affect the likelihood of being offered and eligible for a 401(k) plan.

There is one notable demographic difference in the eligible populations in the two cohorts. In the EBB cohort, Hispanic employees are less likely to be offered and eligible for 401(k) pensions. The marginal effect is highly significant in the presence of controls for firm size, tenure on the job, and full-time work.

We turn now to the determinants of participation in 401(k) plans among eligible employees. Columns 3 and 7 present the marginal effects of the demographic and employmentrelated indicators included in columns 1 and 5, as well as additional measures of financial wealth, risk aversion, and the financial planning horizon. We define employees as participating in a $401(\mathrm{k})$ plan if they made a contribution to a plan during the survey year.

Examining the determinants of participation in the HRS cohort (col. 3), we observe that eligible employees are more likely to participate in a 401(k) plan if they are employed in large firms (more than 100 employees), in white-collar rather than blue-collar jobs, and have tenure greater than five years but no more than 15 years. They are less likely to participate if they are in a union, but having a defined benefit pension in either the current job or a previous job does not affect participation. Employees in trade or in professional services not only are less likely to be eligible, but if eligible, are less likely to participate. While college graduates are more likely to be eligible for a 401(k) plan, they are no more likely to participate than employees with a high school education. Employees with some college education but without a degree, in contrast, are 
no more likely to be eligible for a pension than those with a high school education, but are more likely to participate. Employees whose annual earnings are in the upper three quintiles of the distribution are more likely to participate than those in the lowest quintile. Non-Hispanic other groups have significantly higher participation rates than non-Hispanic white employees.

Married employees in the HRS cohort whose spouses have a DC pension in a current job or had one in a previous job are considerably more likely to participate than those whose spouses never had a DC pension; the latter, interestingly, are less likely to participate than are single employees. Employees (and/or their spouses if married) who hold stock or individual retirement accounts such as IRA or KEOGH accounts are more likely to participate in a 401(k) plan in their current job. Whether their employers offer to match their contributions, however, does not influence their decisions to participate. While employees who report positive levels of risk aversion are significantly more likely to participate, those who claim to engage in long-term financial planning are not more likely to participate.

Participants in the EBB cohort (col. 7) share some characteristics in common with participants in the earlier cohort. Eligible employees in the EBB are more likely to participate if they are white-collar and, if married, have wives who have or had DC pensions in current or previous jobs. They are also more likely to participate if their earnings are in the upper quintiles of the distribution. ${ }^{12}$ In addition, they are no more likely to participate if they engage in longterm financial planning.

There are, however, a number of important differences in the likelihood of participation in the EBB cohort compared to the earlier cohort. Participants in the more recent cohort reflect the broader pool of employees eligible for 401(k) plans. In contrast to employees in the HRS

\footnotetext{
${ }^{12}$ Eligible employees in the EBB cohort whose earnings were in all four upper quintiles were significantly more likely to participate, whereas in the earlier cohort, only those whose earnings were in the highest three quintiles were more likely to participate.
} 
cohort, eligible members of the EBB cohort having attended high school only are equally as likely to participate as those having attended college. Employees across the industrial structure are equally likely to participate in a plan, ${ }^{13}$ as are union and non-union members, and employees in small as well as large firms.

In addition, employees in the EBB cohort who hold stock or IRAs are not necessarily more likely to participate in a 401(k) plan. They are, however, considerably more likely to participate if their employers match their contributions, compared to the earlier cohort. They are also more likely to participate if they have or had a DB pension in their current job or in a previous job. Employees in the EBB cohort with higher levels of risk aversion, moreover, are not more likely to participate in a 401(k) plan, in contrast to those in the earlier cohort. Finally, non-Hispanic other employees in the EBB cohort are not more likely to participate than nonHispanic whites, in contrast to their higher rates in the HRS cohort. Hispanic employees in the more recent cohort, however, are less likely to participate.

Table 2 presents probit regressions of eligibility and participation in 401(k) pensions on pooled samples of the HRS and EBB cohorts. In column (1), the highly significant coefficient on the EBB cohort indicator reveals that we have not captured in this cross-section analysis the full set of explanatory factors associated with the higher observed eligibility rate in the more recent cohort. Employee eligibility may have increased between 1992 and 2004 because of an increase in the number of firms offering 401(k) plans, because eligibility requirements within firms offering these plans were relaxed over this period, or both. Evidence on the growth of 401(k) plans presented earlier suggests that the former explanation is likely to outweigh any relaxation of eligibility restrictions. Full-time employment, for example, is as important in

\footnotetext{
${ }^{13}$ The apparent higher participation in the agriculture, mining, and construction category relative to manufacturing is likely to result from the small sample for this industry group in the EBB cohort.
} 
determining eligibility in the EBB cohort as in the earlier cohort (Table 1), and length of service restrictions on eligibility have traditionally been minimal.

If intrinsic tastes for saving differ between the two cohorts, or if the increasing emphasis between the two interviews in public discussions on the importance of saving for retirement raised employee awareness, we would expect to see a significant marginal effect on the cohort indicator in the pooled regression on participation (col. 3). The marginal effect is not statistically significant (z-value=1.47), although it is sufficiently close to suggest that there may be differences between the two cohorts that we have not captured. ${ }^{14}$

Lastly, we examine the determinants of annual contributions to 401(k) plans among employees reporting contributions to a plan during the survey year. Table 3 presents linear estimates of contributions (in 2004 dollars) for the HRS cohort, the EBB cohort, and a pooled sample of the two cohorts. ${ }^{15}$ In both cohorts, contributions increase monotonically with earnings. Controlling for earnings, household wealth is significantly related to annual contributions only in the highest wealth quintile. While stock ownership is not related to the size of contributions, holders of IRA or KEOGH accounts contribute larger amounts to their current 401(k) plans. The magnitude of this effect is roughly three times larger in the EBB cohort.

Employees in the HRS cohort with defined benefit plans in current or previous jobs were likely to contribute more to their 401(k) plans, but this relationship is not observed in the more recent cohort. Among EBB participants, however, those who reported engaging in financial planning contributed significantly more to their plans. In neither cohort is reported risk aversion

\footnotetext{
${ }^{14}$ While cohort and time effects cannot be disentangled, we have included coverage by a DB pension on current or previous job, stock and IRA/KEOGH holdings, and measures of risk aversion to control for differences in saving propensities between the two cohorts.

${ }^{15}$ The maximum allowable employee contribution in 1992 was $\$ 8,728$ (or \$11,783 in 2004 dollars), whereas in 2004 the maximum allowable contribution was $\$ 16,000$ including a “catch-up contribution” for older employees introduced in 2001.
} 
related to the level of contributions. ${ }^{16}$ Among demographic characteristics, being married or having a spouse with a DC pension of any type in current or previous jobs is not related to contribution amounts in either cohort. In the HRS cohort, college attendance is associated with higher contributions, but the relationship is not observed in the more recent cohort. While nonHispanic others in this cohort were more likely to participate (Table 1), they made smaller contributions to their plans than other racial or ethnic groups. In the EBB cohort, non-Hispanic black employees were equally as likely to participate as non-Hispanic whites (Table 1), but they made larger contributions to their plans. Lastly, the cohort indicator in the pooled contribution sample is large, positive, and highly significant, indicating that there are important omitted characteristics related to differences in tastes for saving or changes over time in the pension environment that are associated with larger contributions among members of the EBB cohort.

\section{Conclusion}

Overall participation in 401(k) pensions increased 46 percent between 1992 and 2004 among employees ages 51-56 representing two cohorts, one born before World War II and the other born immediately after the war. This substantial growth in 401(k) plan participation may reflect intrinsic differences in tastes between the two cohorts, changes between 1992 and 2004 in the external environment regarding the importance of saving for retirement, or the joint effect of both influences.

\footnotetext{
${ }^{16}$ The large and positive coefficient on the indicator for missing observations in the EBB cohort is likely to be a function of sample size $(\mathrm{N}=24)$.
} 


\section{References}

Andrews, Emily S. 1992. "The Growth and Distribution of 401(k) Plans.” In Trends in Pensions 1992, edited by John A. Turner and Daniel J. Beller, 149-76. Washington D.C.: U.S. Department of Labor.

Basett, William F., Michael J. Fleming, and Anthony P. Rodrigues. 1998. "How Workers Use 401(k) Plans, The Participation, Contribution, and Withdrawal Decisions.” National Tax Journal 51 No. 2 (June): 263-89.

Bernheim, Douglas B., and Daniel M. Garrett. 1996. "The Determinants and Consequences of Financial Education in the Workplace: Evidence from a Survey of Households.” NBER Working paper No. 5667. Cambridge, MA: National Bureau of Economic Research.

Buessing, Marric, and Mauricio Soto. 2006. “The State of Private Pensions: Current 5500 Data.” Center for Retirement Research, Boston College.

Clark, Robert L., and Sylvester J. Schieber. 1998. "Factors Affecting Participation Rates and Contribution Levels in 401(k) Plans.” In Living with Defined Contribution Pensions: Remaking Responsibility for Retirement, edited by Olivia S. Mitchell and Sylvester J. Schieber, 69-97. Philadelphia: University of Pennsylvania Press.

Cunningham, Christopher R., and Gary V. Engelhardt. 2002. "Federal Tax Policy, Employer Matching, and 401(k) Saving: Evidence from HRS W-2 Records.” National Tax Journal Vol. LV, No. 3, (September): 617-645.

Engelhardt, Gary V. 2001 "Have 401(k)s Raised Household Saving? Evidence from the Health and Retirement Study.” Syracuse University. Mimeo.

Gustman, Alan L., and Thomas L. Steinmeier. 1999b. "Effects of Pensions on Savings: Analysis with Data from the Health and Retirement Study.” Carnegie-Rochester Series on Public Policy 50: 271-326.

Gustman, Alan L., and Thomas L. Steinmeier. 1999c. "What People Don’t Know About Pensions and Social Security: An Analysis Using Linked Data from the health and Retirement Study.” NBER Working Paper No. 7368. Cambridge, MA: National Bureau of Economic Research.

Moon, Marilyn, and F. Thomas Juster. 1995. "Economic Status Measures in the Health and Retirement Study.” Journal of Human Resources 30 (Supplement): S138-S157.

Munnell, Alicia H., Annika Sunden, and Catherine Taylor. 2001. "What Determines 401(k) Participation and Contributions?” Center for Retirement Research, Boston College.

Papke, Leslie E. 1995. "Participation in and Contributions to 401(k) Pension Plans: Evidence from Panel Data.” Journal of Human Resources 30 No.2 (Spring): 311-25. 
Papke, Leslie E. 2003. “Individual Financial Decisions in Retirement Saving Plans: The Role of Participant-Direction.” Journal of Public Economics 88: 39-61.

Papke, Leslie E. and James M. Poterba. 1995. "Survey Evidence on Employer Match Rates and Employee Saving Behavior in 401(k) Plans.” Economics Letters 49: 313-317.

Pence, Karen M. 1999. “401(k)s and Household Saving: New Evidence from the Survey of Consumer Finances.” University of Wisconsin-Madison. Mimeo.

Poterba, James M., Steve F. Venti, and David A. Wise. 1994. “401(k) Plans and Tax-Deferred Savings.” In David A. Wise (ed.), Studies in the Economics of Aging. Chicago: University of Chicago Press, pp. 105-42.

Poterba, James M., Steve F. Venti, and David A. Wise. 1995. “Do 401(k) Contributions Crowd Out Other Personal Saving?” Journal of Public Economics 58:1-32.

Smith, James P. 1995. "Racial and Ethnic Differences in Wealth in the Health and retirement Study.” Journal of Human Resources 30 (Supplement): S158-S183.

Smith, Karen E., Richard W. Johnson, and Leslie A. Muller. 2004. "Deferring Income in Employer-Sponsored Retirement Plans: The Dynamics of Participant Contributions.” The Urban Institute, September. 
Table 1. Probit Estimates of Eligibility and Participation in a 401(k) Pension on the Current Job

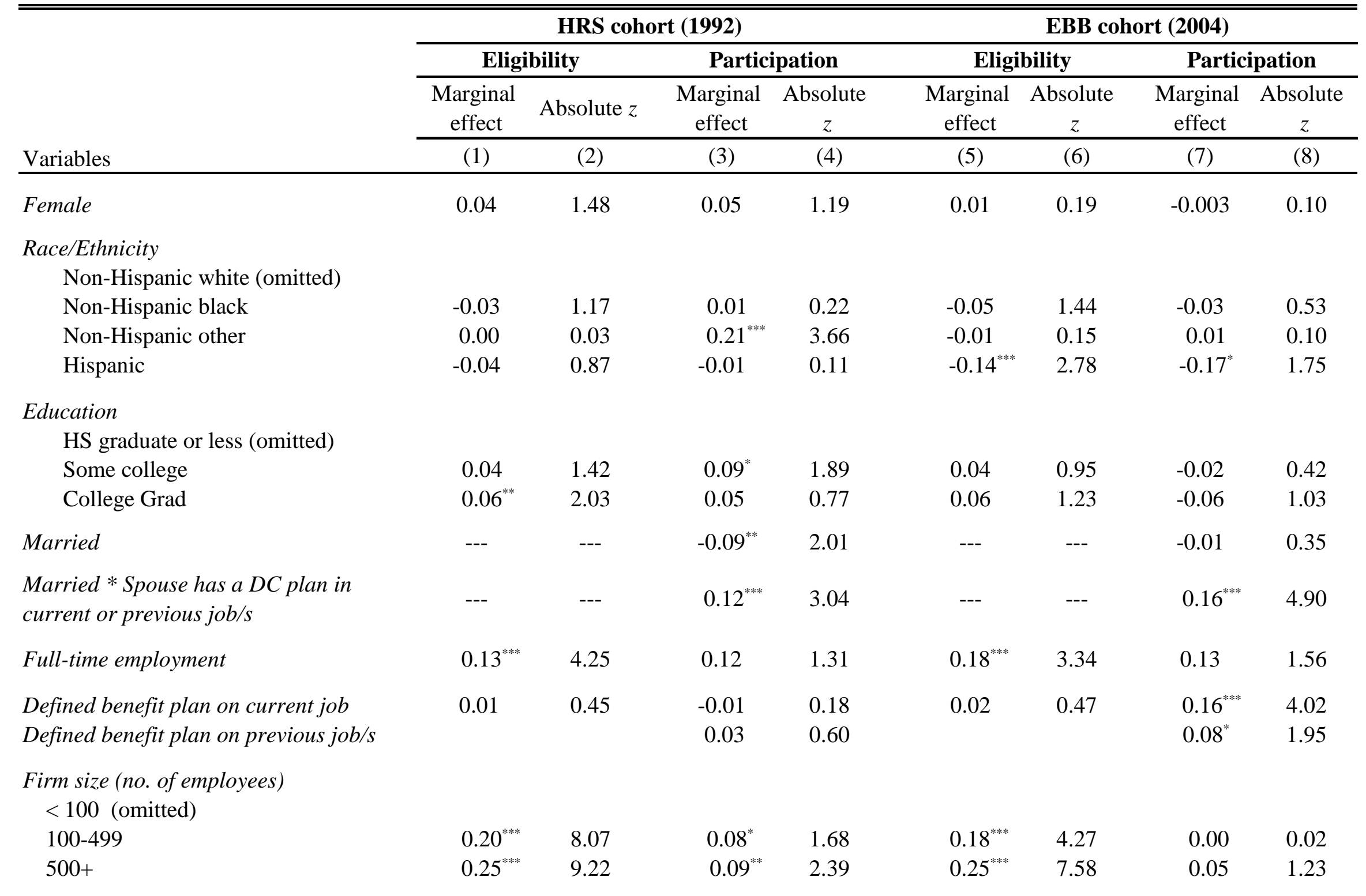




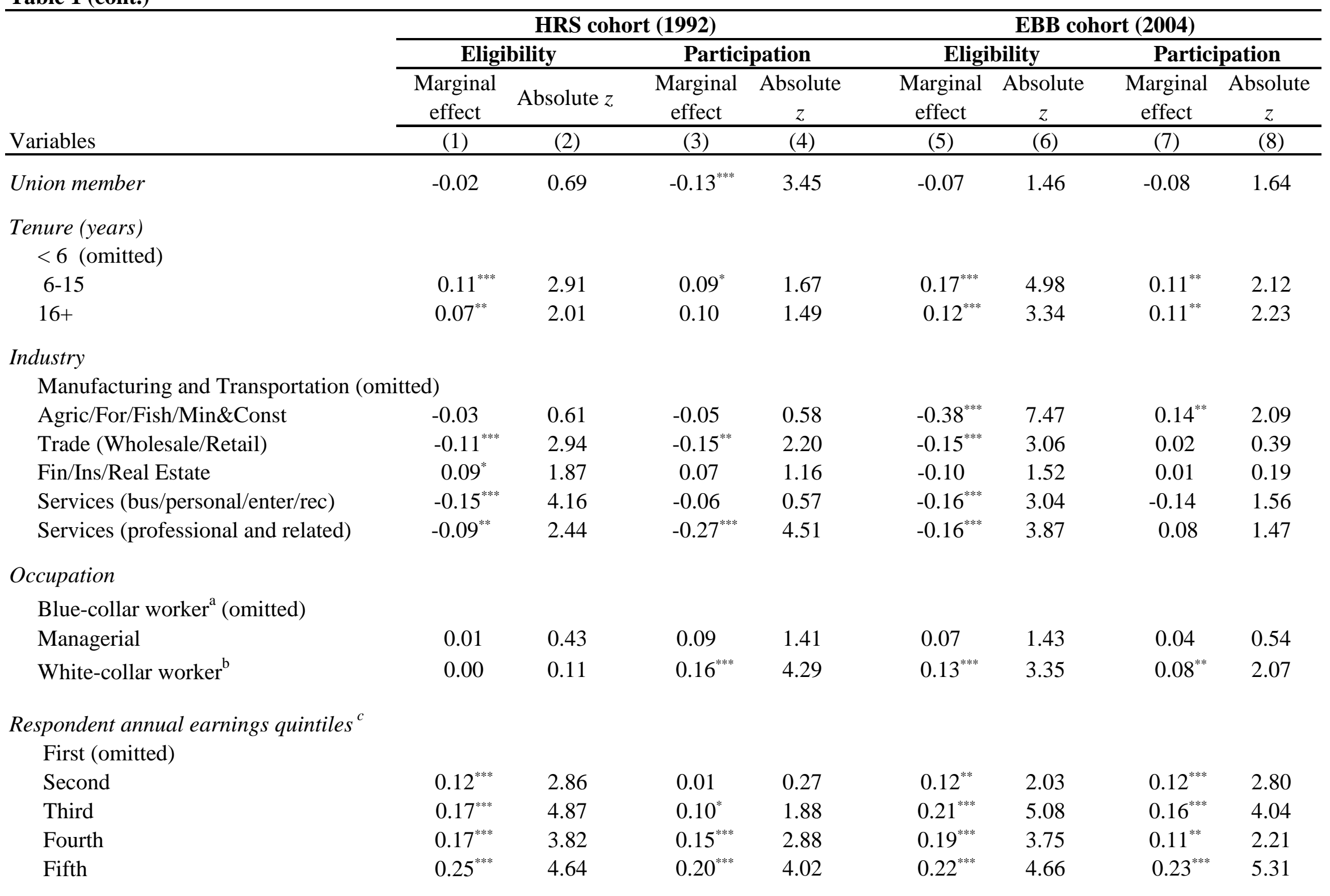




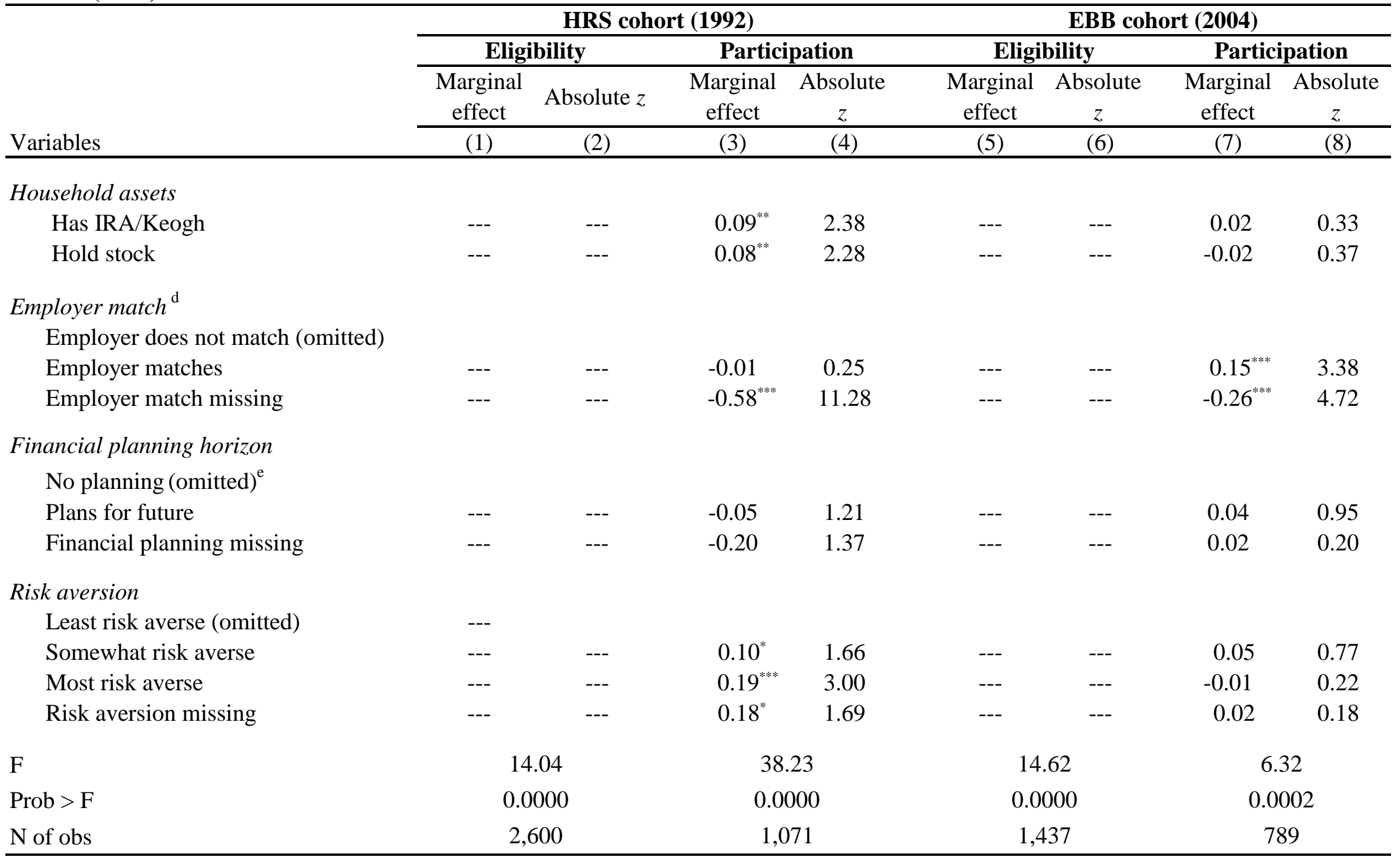




\section{Table 1 (cont.)}

Notes: Estimates are based on data from the 1992 interview of the HRS cohort and the 2004 interview of the EBB cohort. The sample for each cohort consists of private sector wage-earners ages 51-56 who reported they were either included in a pension (DC, DB, or both) or not included but provided valid answers to whether their employers offered a pension. Respondents are defined as being eligible if they reported either being included in, or offered and eligible for, a 401(k) plan. For respondents in the HRS cohort who reported being included in a DB plan only, we use information from employer data to determine their 401(k) eligibility. Respondents whose employer offered both a DB and a DC plan are considered eligible for a 401(k) plan, whereas those whose employer offered only a DB plan are considered not eligible. Respondents who reported being included in a DB plan only, and for whom employer information was missing, are not retained in the sample. The 401(k) eligibility status of respondents in the EBB cohort who reported being included in a DB plan only is based on a follow-up question (not available for the HRS cohort) regarding whether their employers offered a 401(k) plan. Eligible employees are defined as participants if they report a positive contribution during the survey year. Household weights are used.

${ }^{a}$ Blue-collar worker category includes farming/forestry/fishing, mechanics/repair, and construction/trade/extractors.

${ }^{\mathrm{b}}$ White-collar worker category includes sales and clerical/administrative support.

${ }^{c}$ Annual earnings quintiles are derived separately for the eligibility and participation samples. Respondent annual earnings are in \$2004.

${ }^{\mathrm{d}}$ Respondents eligible for a 401(k) are asked if their employer makes a matching contribution. Respondents who either did not know about a match, or who reported a DB plan and therefore were not asked about an employer match but whose employers reported offering both a DB and a DC plan are classified as missing in the employer match variable.

e The category "No planning" includes respondents reporting their financial planning horizon as "next few months or next year." The category "Plans for future" includes those who report planning for the "next few years or 5+ years."

Statistical significance at the 10,5 and 1 percent levels is denoted by ${ }^{*},{ }^{* *}$ and ${ }^{* * *}$, respectively. 
Table 2. Probit Estimates of Eligibility and Participation in a 401(k) Pension on the Current Job: HRS and EBB Samples Pooled

\begin{tabular}{|c|c|c|c|c|}
\hline \multirow[b]{3}{*}{ Variables } & \multicolumn{2}{|c|}{ Eligibility } & \multicolumn{2}{|c|}{ Participation } \\
\hline & $\begin{array}{c}\text { Marginal } \\
\text { effect }\end{array}$ & Absolute $z$ & $\begin{array}{c}\text { Marginal } \\
\text { effect }\end{array}$ & Absolute $z$ \\
\hline & $(1)$ & $(2)$ & (3) & $(4)$ \\
\hline Female & 0.01 & 0.60 & 0.01 & 0.48 \\
\hline \multicolumn{5}{|l|}{ Race/Ethnicity } \\
\hline Non-Hispanic black & $-0.04^{*}$ & 1.80 & -0.03 & 0.71 \\
\hline Non-Hispanic other & 0.00 & 0.00 & 0.07 & 0.80 \\
\hline Hispanic & $-0.11^{* * * *}$ & 2.93 & -0.10 & 1.46 \\
\hline \multicolumn{5}{|l|}{ Education } \\
\hline \multicolumn{5}{|l|}{ HS graduate or less (omitted) } \\
\hline Some college & 0.04 & 1.40 & 0.01 & 0.19 \\
\hline College Grad & $0.07^{* *}$ & 2.09 & -0.04 & 0.86 \\
\hline Married & & & -0.05 & 1.53 \\
\hline $\begin{array}{l}\text { Married * Spouse has a DC plan in current or } \\
\text { previous job/s }\end{array}$ & --- & --- & $0.15^{* * *}$ & 6.10 \\
\hline Full-time employment & $0.16^{* * *}$ & 4.75 & $0.13^{* *}$ & 2.37 \\
\hline Defined benefit plan on current job & 0.01 & 0.53 & $0.12^{* * * *}$ & 3.60 \\
\hline Defined benefit plan on previous job/s & & & $0.07^{* *}$ & 1.98 \\
\hline \multicolumn{5}{|l|}{ Firm size (no. of employees) } \\
\hline \multicolumn{5}{|l|}{$<100$ (omitted) } \\
\hline $100-499$ & $0.19^{* * *}$ & 7.28 & 0.04 & 1.35 \\
\hline $500+$ & $0.25^{* * *}$ & 10.99 & $0.07^{* *}$ & 1.97 \\
\hline Union member & -0.04 & 1.51 & $-0.10^{* * *}$ & 2.56 \\
\hline \multicolumn{5}{|l|}{ Tenure (years) } \\
\hline \multicolumn{5}{|l|}{ <6 (omitted) } \\
\hline $6-15$ & $0.15^{* * *}$ & 5.90 & $0.11^{* * *}$ & 2.71 \\
\hline $16+$ & $0.10^{* * *}$ & 3.56 & $0.12^{* * *}$ & 3.27 \\
\hline \multicolumn{5}{|l|}{ Industry } \\
\hline \multicolumn{5}{|l|}{ Manufacturing and Transportation (omitted) } \\
\hline Agric/For/Fish/Min\&Const & $-0.23^{* * *}$ & 5.78 & 0.06 & 0.95 \\
\hline Trade (Wholesale/Retail) & $-0.13^{* * *}$ & 4.21 & -0.02 & 0.37 \\
\hline Fin/Ins/Real Estate & -0.02 & 0.34 & 0.04 & 0.78 \\
\hline Services (bus/personal/enter/rec) & $-0.15^{* * *}$ & 4.19 & $-0.12^{*}$ & 1.67 \\
\hline Services (professional and related) & $-0.13^{* * * *}$ & 4.07 & -0.01 & 0.18 \\
\hline
\end{tabular}


Table 2 (cont.)

\begin{tabular}{|c|c|c|c|c|}
\hline \multirow[b]{3}{*}{ Variables } & \multicolumn{2}{|c|}{ Eligibility } & \multicolumn{2}{|c|}{ Participation } \\
\hline & $\begin{array}{c}\text { Marginal } \\
\text { effect }\end{array}$ & Absolute $z$ & $\begin{array}{c}\text { Marginal } \\
\text { effect }\end{array}$ & Absolute $z$ \\
\hline & $(1)$ & (2) & $(3)$ & $(4)$ \\
\hline \multicolumn{5}{|l|}{ Occupation } \\
\hline \multicolumn{5}{|l|}{ Blue-collar worker (omitted) } \\
\hline Managerial & 0.04 & 1.35 & 0.06 & 1.20 \\
\hline White-collar worker & $0.08^{* * *}$ & 2.88 & $0.10^{* * *}$ & 3.19 \\
\hline \multicolumn{5}{|c|}{ Respondent annual earnings quintiles } \\
\hline \multicolumn{5}{|c|}{ First (omitted) } \\
\hline Second & $0.13^{* * *}$ & 3.58 & $0.11^{* * *}$ & 2.88 \\
\hline Third & $0.20^{* * *}$ & 6.80 & $0.16^{* * *}$ & 4.81 \\
\hline Fourth & $0.19^{* * *}$ & 4.98 & $0.12^{* * *}$ & 3.22 \\
\hline Fifth & $0.24^{* * *}$ & 7.09 & $0.22^{* * *}$ & 6.03 \\
\hline \multicolumn{5}{|l|}{ Household assets } \\
\hline Has IRA/Keogh & --- & --- & 0.03 & 1.08 \\
\hline Has stock & --- & --- & 0.02 & 0.56 \\
\hline \multicolumn{5}{|l|}{ Employer match } \\
\hline \multicolumn{5}{|c|}{ Employer does not match (omitted) } \\
\hline Employer matches & --- & --- & $0.10^{* * *}$ & 3.06 \\
\hline Employer match missing & --- & --- & $-0.34^{* * *}$ & 8.66 \\
\hline \multicolumn{5}{|l|}{ Financial planning horizon } \\
\hline \multicolumn{5}{|l|}{ No planning (omitted) } \\
\hline Plans for future & --- & --- & 0.01 & 0.16 \\
\hline Financial planning missing & --- & --- & -0.05 & 0.58 \\
\hline \multicolumn{5}{|l|}{ Risk aversion } \\
\hline \multicolumn{5}{|l|}{ Least risk averse (omitted) } \\
\hline Somewhat risk averse & --- & --- & 0.07 & 1.39 \\
\hline Most risk averse & --- & --- & 0.04 & 1.00 \\
\hline Risk aversion missing & --- & --- & 0.07 & 0.76 \\
\hline EBB Cohort & $0.17^{* * *}$ & 9.54 & 0.04 & 1.47 \\
\hline $\mathrm{F}$ & \multicolumn{2}{|c|}{19.27} & \multicolumn{2}{|c|}{8.85} \\
\hline Prob $>$ F & \multicolumn{2}{|c|}{0.0000} & \multicolumn{2}{|c|}{0.0000} \\
\hline $\mathrm{N}$ of obs & \multicolumn{2}{|c|}{4,037} & \multicolumn{2}{|c|}{1,860} \\
\hline
\end{tabular}

Notes : See notes in Table 1. 
Table 3. OLS Estimates of Annual Contributions (\$) to a 401(k) Pension among Participants ${ }^{1}$

\begin{tabular}{|c|c|c|c|c|c|c|}
\hline \multirow[b]{3}{*}{ Variables } & \multicolumn{2}{|c|}{ HRS cohort (1992) } & \multicolumn{2}{|c|}{ EBB cohort (2004) } & \multicolumn{2}{|c|}{ Pooled Sample } \\
\hline & Coefficient & Absolute t & Coefficient & Absolute t & Coefficient & Absolute $\mathrm{t}$ \\
\hline & $(1)$ & $(2)$ & (3) & $(4)$ & $(5)$ & $(6)$ \\
\hline Female & 215 & 1.02 & 241 & 0.62 & 328 & 1.21 \\
\hline \multicolumn{7}{|l|}{ Race/Ethnicity } \\
\hline Non-Hispanic black & -420 & 1.50 & $795^{*}$ & 1.83 & 362 & 1.01 \\
\hline Non-Hispanic other & $-565^{*}$ & 1.92 & 424 & 0.75 & -127 & 0.28 \\
\hline Hispanic & -217 & 0.49 & -218 & 0.41 & -234 & 0.55 \\
\hline \multicolumn{7}{|l|}{ Education } \\
\hline Some college & $598^{* * *}$ & 2.95 & 508 & 1.34 & $513^{*}$ & 1.92 \\
\hline College Grad & 241 & 0.93 & 490 & 1.32 & 392 & 1.55 \\
\hline Married & 180 & 0.57 & 551 & 0.99 & 340 & 0.91 \\
\hline $\begin{array}{l}\text { Married * Spouse has a DC plan in current } \\
\text { or previous job/s }\end{array}$ & 100 & 0.51 & 45 & 0.11 & 175 & 0.62 \\
\hline Defined benefit plan on current job & $425^{* *}$ & 2.16 & -253 & 0.92 & -76 & 0.36 \\
\hline Defined benefit plan on previous job/s & $413^{*}$ & 1.69 & 20 & 0.05 & 140 & 0.51 \\
\hline \multicolumn{7}{|l|}{ Respondent annual earnings quintiles } \\
\hline Second & $1373^{* * *}$ & 7.33 & $688^{*}$ & 1.85 & $901^{* * *}$ & 3.82 \\
\hline Third & $2230^{* * *}$ & 8.50 & $2354^{* * *}$ & 4.55 & $2288^{* * *}$ & 6.65 \\
\hline Fourth & $3322^{* * *}$ & 9.16 & $3075^{* * *}$ & 5.67 & $3160^{* * *}$ & 8.45 \\
\hline Fifth & $4237^{* * *}$ & 11.91 & $7082^{* * *}$ & 10.72 & $6337^{* * *}$ & 13.7 \\
\hline
\end{tabular}


Table 3 (cont.)

\begin{tabular}{|c|c|c|c|c|c|c|}
\hline \multirow[b]{3}{*}{ Variables } & \multicolumn{2}{|c|}{ HRS cohort (1992) } & \multicolumn{2}{|c|}{ EBB cohort (2004) } & \multicolumn{2}{|c|}{ Pooled Sample } \\
\hline & Coefficient & Absolute $\mathrm{t}$ & Coefficient & Absolute t & Coefficient & Absolute t \\
\hline & $(1)$ & $(2)$ & (3) & $(4)$ & $(5)$ & $(6)$ \\
\hline \multicolumn{7}{|l|}{ Household wealth quintiles ${ }^{2}$} \\
\hline Second & 206 & 0.74 & -434 & -0.90 & -189 & 0.55 \\
\hline Third & 302 & 0.93 & -57 & -0.09 & 9 & 0.02 \\
\hline Fourth & 436 & 1.13 & 831 & 1.37 & $823^{* *}$ & 2.04 \\
\hline Fifth & $1580^{* * *}$ & 3.80 & $1593^{* *}$ & 2.21 & $1677^{* * *}$ & 2.93 \\
\hline \multicolumn{7}{|l|}{ Household assets } \\
\hline Has IRA/Keogh & $410^{*}$ & 1.89 & $1167^{* * *}$ & 3.09 & $933^{* * *}$ & 3.47 \\
\hline Hold stock & 80 & 0.42 & 70 & 0.22 & 116 & 0.58 \\
\hline \multicolumn{7}{|l|}{ Financial planning horizon } \\
\hline \multicolumn{7}{|l|}{ No planning (omitted) } \\
\hline Plans for future & 44 & 0.14 & $1160^{* * *}$ & 2.91 & $860^{* * *}$ & 2.83 \\
\hline Financial planning missing & $-1009^{*}$ & 1.74 & 198 & 0.15 & -7 & 0.01 \\
\hline \multicolumn{7}{|l|}{ Risk aversion } \\
\hline Somewhat risk averse & 480 & 1.19 & -278 & 0.48 & -135 & 0.32 \\
\hline Most risk averse & 352 & 1.26 & -76 & 0.16 & 74 & 0.22 \\
\hline Risk aversion missing ${ }^{3}$ & 546 & 0.99 & $3390^{* * *}$ & 2.84 & $2546^{* * *}$ & 2.74 \\
\hline EBB Cohort & --- & --- & --- & --- & $1385^{* * *}$ & 6.11 \\
\hline $\mathrm{R}^{2}$ & \multicolumn{2}{|c|}{0.46} & \multicolumn{2}{|c|}{0.53} & \multicolumn{2}{|c|}{0.50} \\
\hline $\mathrm{N}$ of obs & \multicolumn{2}{|c|}{622} & \multicolumn{2}{|c|}{475} & \multicolumn{2}{|c|}{1097} \\
\hline
\end{tabular}


Appendix Table 1. Sample means: HRS and EBB Cohorts

\begin{tabular}{|c|c|c|c|c|c|c|}
\hline \multirow[b]{3}{*}{ Variables } & \multicolumn{3}{|c|}{$\begin{array}{r}\text { HRS cohort (1992) } \\
\end{array}$} & \multicolumn{3}{|c|}{$\begin{array}{c}\text { EBB cohort (2004) } \\
\end{array}$} \\
\hline & $\begin{array}{l}\text { Eligible } \\
\text { workers }\end{array}$ & Participants & $\begin{array}{c}\text { Non- } \\
\text { Participants }\end{array}$ & $\begin{array}{l}\text { Eligible } \\
\text { workers }\end{array}$ & Participants & $\begin{array}{c}\text { Non- } \\
\text { Participants }\end{array}$ \\
\hline & $(1)$ & $(2)$ & $(3)$ & $(4)$ & $(5)$ & $(6)$ \\
\hline Female & 0.43 & 0.42 & 0.47 & 0.42 & 0.40 & 0.47 \\
\hline \multicolumn{7}{|l|}{ Race/Ethnicity } \\
\hline Non-Hispanic white & 0.85 & 0.87 & 0.82 & 0.81 & 0.84 & 0.74 \\
\hline Non-Hispanic black & 0.08 & 0.06 & 0.12 & 0.09 & 0.08 & 0.13 \\
\hline Non-Hispanic other & 0.03 & 0.04 & 0.01 & 0.04 & 0.04 & 0.04 \\
\hline Hispanic & 0.04 & 0.04 & 0.05 & 0.06 & 0.04 & 0.10 \\
\hline \multicolumn{7}{|l|}{ Education } \\
\hline HS graduate or less & 0.48 & 0.42 & 0.59 & 0.30 & 0.28 & 0.36 \\
\hline Some college & 0.23 & 0.26 & 0.18 & 0.31 & 0.31 & 0.31 \\
\hline College Grad & 0.29 & 0.32 & 0.24 & 0.39 & 0.41 & 0.34 \\
\hline Married & 0.76 & 0.76 & 0.78 & 0.75 & 0.76 & 0.72 \\
\hline $\begin{array}{l}\text { Married } * \text { Spouse has a DC plan in } \\
\text { current or previous job/s }\end{array}$ & 0.28 & 0.32 & 0.22 & 0.40 & 0.45 & 0.27 \\
\hline Full-time employment & 0.93 & 0.96 & 0.88 & 0.93 & 0.95 & 0.89 \\
\hline Defined benefit plan on current job & 0.51 & 0.51 & 0.52 & 0.39 & 0.42 & 0.34 \\
\hline Defined benefit plan on previous job/s & 0.23 & 0.24 & 0.22 & 0.21 & 0.23 & 0.15 \\
\hline \multicolumn{7}{|l|}{ Firm size (no. of employees) } \\
\hline$<100$ & 0.28 & 0.23 & 0.38 & 0.25 & 0.23 & 0.31 \\
\hline $100-499$ & 0.26 & 0.26 & 0.25 & 0.23 & 0.21 & 0.26 \\
\hline $500+$ & 0.46 & 0.50 & 0.37 & 0.52 & 0.56 & 0.44 \\
\hline Union member & 0.28 & 0.23 & 0.39 & 0.22 & 0.20 & 0.26 \\
\hline
\end{tabular}




\section{Appendix Table 1 (cont.)}

\begin{tabular}{|c|c|c|c|c|c|c|}
\hline \multirow[b]{3}{*}{ Variables } & \multicolumn{3}{|c|}{ "HRS cohort (1992) } & \multicolumn{3}{|c|}{ EBB cohort (2004) } \\
\hline & $\begin{array}{c}\text { Eligible } \\
\text { workers }\end{array}$ & Participants & $\begin{array}{c}\text { Non- } \\
\text { Participants }\end{array}$ & $\begin{array}{c}\text { Eligible } \\
\text { workers }\end{array}$ & Participants & $\begin{array}{c}\text { Non- } \\
\text { Participants }\end{array}$ \\
\hline & $(1)$ & $(2)$ & $(3)$ & $(4)$ & $(5)$ & $(6)$ \\
\hline \multicolumn{7}{|l|}{ Tenure (years) } \\
\hline$<6$ & 0.23 & 0.20 & 0.29 & 0.26 & 0.22 & 0.33 \\
\hline $6-15$ & 0.32 & 0.33 & 0.30 & 0.36 & 0.38 & 0.33 \\
\hline $16+$ & 0.45 & 0.47 & 0.41 & 0.38 & 0.40 & 0.34 \\
\hline \multicolumn{7}{|l|}{ Industry } \\
\hline Manufacturing and Transportation & 0.40 & 0.45 & 0.32 & 0.35 & 0.35 & 0.35 \\
\hline Agric/For/Fish/Min\&Const & 0.06 & 0.05 & 0.08 & 0.03 & 0.04 & 0.03 \\
\hline Trade (Wholesale/Retail) & 0.10 & 0.08 & 0.12 & 0.14 & 0.13 & 0.15 \\
\hline Fin/Ins/Real Estate & 0.10 & 0.13 & 0.04 & 0.08 & 0.09 & 0.07 \\
\hline Services (bus/personal/enter/rec) & 0.06 & 0.06 & 0.05 & 0.07 & 0.06 & 0.08 \\
\hline Services (professional and related) & 0.29 & 0.24 & 0.38 & 0.33 & 0.33 & 0.33 \\
\hline \multicolumn{7}{|l|}{ Occupation } \\
\hline Blue-collar worker & 0.35 & 0.27 & 0.50 & 0.30 & 0.26 & 0.39 \\
\hline Managerial & 0.41 & 0.47 & 0.30 & 0.41 & 0.44 & 0.34 \\
\hline White-collar worker & 0.24 & 0.26 & 0.20 & 0.29 & 0.30 & 0.26 \\
\hline \multicolumn{7}{|l|}{ Respondent annual earnings quintiles } \\
\hline First & 15,156 & 16,376 & 14,164 & 16,585 & 18,420 & 14,792 \\
\hline Second & 29,585 & 29,591 & 29,577 & 32,090 & 31,984 & 32,339 \\
\hline Third & 42,479 & 42,327 & 42,796 & 44,650 & 44,397 & 45,301 \\
\hline Fourth & 58,540 & 58,330 & 59,122 & 61,875 & 61,878 & 61,868 \\
\hline Fifth & 106,920 & 108,290 & 100,632 & 135,064 & 137,778 & 119,012 \\
\hline
\end{tabular}




\section{Appendix Table 1 (cont.)}

\begin{tabular}{|c|c|c|c|c|c|c|}
\hline \multirow[b]{3}{*}{ Variables } & \multicolumn{3}{|c|}{ HRS cohort (1992) } & \multicolumn{3}{|c|}{ EBB cohort (2004) } \\
\hline & $\begin{array}{c}\text { Eligible } \\
\text { workers }\end{array}$ & Participants & $\begin{array}{c}\text { Non- } \\
\text { Participants }\end{array}$ & $\begin{array}{l}\text { Eligible } \\
\text { workers }\end{array}$ & Participants & $\begin{array}{c}\text { Non- } \\
\text { Participants }\end{array}$ \\
\hline & $(1)$ & $(2)$ & (3) & $(4)$ & $(5)$ & $(6)$ \\
\hline \multicolumn{7}{|l|}{ Household wealth quintiles } \\
\hline First & 7,099 & -842 & 15,446 & $-15,806$ & $-23,664$ & $-2,590$ \\
\hline Second & 80,660 & 81,233 & 79,754 & 68,982 & 69,391 & 68,261 \\
\hline Third & 144,679 & 147,638 & 139,235 & 159,365 & 159,595 & 158,781 \\
\hline Fourth & 241,834 & 244,319 & 235,070 & 320,665 & 324,852 & 309,007 \\
\hline Fifth & 659,941 & 631,932 & 743,480 & $1,005,204$ & 941,323 & $1,205,005$ \\
\hline \multicolumn{7}{|l|}{ Household assets } \\
\hline Has IRA/Keogh & 0.52 & 0.58 & 0.39 & 0.47 & 0.51 & 0.39 \\
\hline Hold stock & 0.40 & 0.46 & 0.28 & 0.34 & 0.36 & 0.29 \\
\hline \multicolumn{7}{|l|}{ Employer match } \\
\hline Employer does not match (omitted) & 0.17 & 0.22 & 0.08 & 0.15 & 0.15 & 0.15 \\
\hline Employer matches & 0.52 & 0.66 & 0.27 & 0.59 & 0.67 & 0.38 \\
\hline Employer match missing & 0.31 & 0.13 & 0.65 & 0.26 & 0.17 & 0.47 \\
\hline \multicolumn{7}{|l|}{ Financial planning horizon } \\
\hline No planning & 0.18 & 0.17 & 0.20 & 0.17 & 0.15 & 0.24 \\
\hline Plans for future & 0.76 & 0.78 & 0.72 & 0.76 & 0.80 & 0.68 \\
\hline Financial planning missing & 0.06 & 0.05 & 0.08 & 0.06 & 0.05 & 0.09 \\
\hline \multicolumn{7}{|l|}{ Risk aversion } \\
\hline Least risk averse & 0.10 & 0.09 & 0.13 & 0.10 & 0.11 & 0.10 \\
\hline Somewhat risk averse & 0.23 & 0.24 & 0.22 & 0.30 & 0.33 & 0.23 \\
\hline Most risk averse & 0.61 & 0.63 & 0.57 & 0.53 & 0.51 & 0.59 \\
\hline Risk aversion missing & 0.06 & 0.05 & 0.08 & 0.07 & 0.06 & 0.09 \\
\hline $\mathrm{N}$ of obs & 1,071 & 674 & 397 & 789 & 543 & 246 \\
\hline
\end{tabular}

Notes: See notes in Table 1 and Table 3. 